AL. $2.2009-191$

c. $\partial$

\section{Fish \& Wildlife} Division

\section{SPECIES AT RISK}

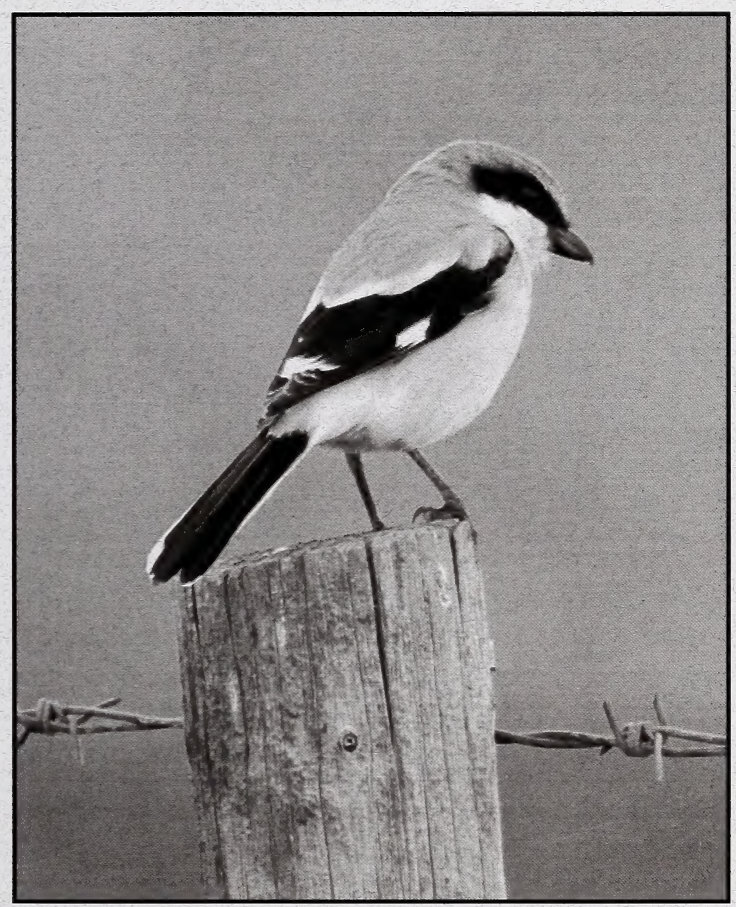

Alberta Species at Risk Report No. 127

\section{The 2008 Loggerhead Shrike Survey in Alberta}


Digitized by the Internet Archive in 2016

https://archive.org/details/2008loggerheadsh00pres_0 


\title{
The 2008 Loggerhead Shrike Survey in Alberta
}

\author{
David R. C. Prescott
}

Alberta Species at Risk Report No. 127

July 2009 
Publication No.: I/389

ISBN: 978-0-7785-8702-6 (Printed Edition)

ISBN: 978-0-7785-8703-3 (Online Edition)

ISSN: 1496-7219 (Printed Edition)

ISSN: 1496-7146 (Online Edition)

Cover Photograph: Dave Prescott

For copies of this report, contact:

Information Centre - Publications

Alberta Environment / Alberta Sustainable Resource Development

Main Floor, Great West Life Building

9920108 Street

Edmonton, Alberta, Canada T5K 2M4

Telephone: (780) 422-2079

OR

Visit our web site at:

http://www3.gov.ab.ca/srd/fw/speciesatrisk/

This publication may be cited as:

Prescott, D. R. C. 2009. The 2008 Loggerhead Shrike Survey in Alberta. Alberta Sustainable Resource Development, Fish and Wildlife Division, Alberta Species at Risk Report No. 127, Edmonton, AB. 14 pp. 


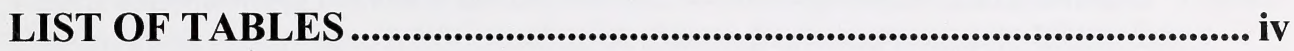

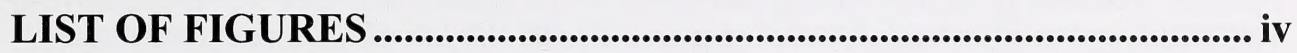

ACKNOWLEDGEMENTS ...................................................................................... v

EXECUTIVE SUMMARY .............................................................................. vi

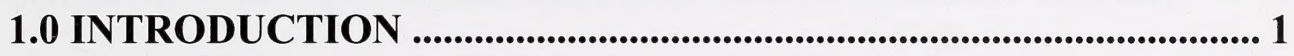

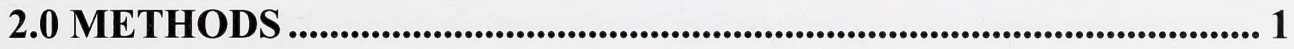

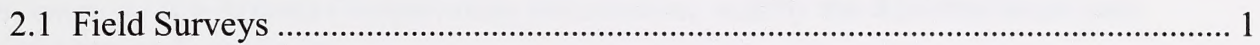

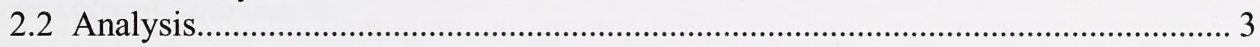

2.3 HSI Model Validation.................................................................................... 3

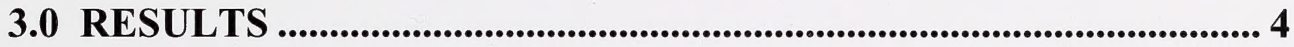

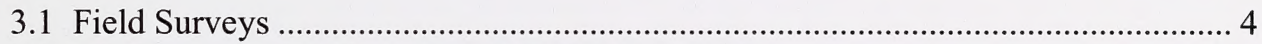

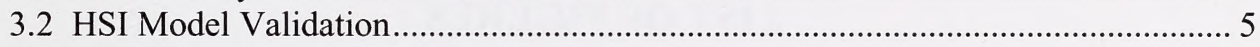

4.0 DISCUSSION ................................................................................................... 7

5.0 RECOMMENDATIONS/FUTURE DIRECTION............................... 10

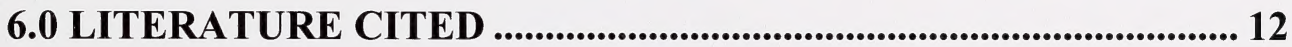




\section{LIST OF TABLES}

Table 1. Summary of Loggerhead Shrike roadside survey results in each of eight, 1:250,000 map sheets in southeastern Alberta in 2008

Table 2. Number of indicated breeding pairs (IP) per $100 \mathrm{~km}$ of road, and percentage change in population size among three roadside surveys conducted in Alberta 6

Table 3. Comparison of four HSI metrics within $200 \mathrm{~m}$ of occupied sites ("actual") and random points for Loggerhead Shrikes observed during the 2003 and 2008 provincial roadside surveys................................................. 8

Table 4. Comparison of four HSI metrics within $1000 \mathrm{~m}$ of occupied sites ("actual") and random points for Loggerhead Shrikes observed during the 2003 and 2008 provincial roadside surveys...................................................

\section{LIST OF FIGURES}

Figure 1. Location of road survey routes used in the 2008 Loggerhead Shrike survey in

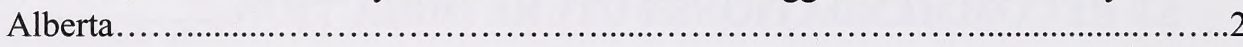




\section{ACKNOWLEDGEMENTS}

I thank the following staff of Alberta Fish and Wildlife Division and the Alberta

Conservation Association for conducting or assisting on road routes during the 2008 provincial survey: Francois Blouin, Grant Chapman, Chad Croft, Brad Downey, Brandy Downey, Leo Dube, Lance Engley, Shannon Frank, Ken Froggatt, Laura Froggatt, Ed Hofman, Darryl Jarina, Paul Jones, Doug Manzer, Dave Moore, Kim Morton, Joel Nicholson, Reg Russell, Scott Stevens, and Pat Young. I also thank Al Violette for collating and summarizing HSI data in preparation for analysis, Ken De Smet and Andy Didiuk for providing recent information from Manitoba and Saskatchewan, and Scott Stevens and Lance Engley for reviewing a draft of this document.

The project was supported by the Species at Risk Program of Alberta Fish and Wildlife Division, by the Alberta Conservation Association, and by the TD Friends of the Environment Foundation. 


\section{EXECUTIVE SUMMARY}

Populations of the Loggerhead Shrike (Lanius ludovicianus) have declined in recent years, and populations in western Canada (L. l. exubitorides) are listed by the Committee on the Status of Endangered Wildlife in Canada as being "Threatened". The species is considered to be of "Special Concern" in Alberta. A prairie-wide roadside survey has been conducted every five years since 1987 to monitor populations of the Loggerhead Shrike. This report summarizes results of the 2008 survey conducted in Alberta, and compares results with surveys conducted in 1987, 1998 and 2003 (a 1993 survey conducted in Manitoba and Saskatchewan was not done in this province). An additional objective of the 2008 survey was to validate a recently developed Habitat Suitability Index (HSI) model for the Loggerhead Shrike in Alberta.

The 2008 survey was conducted by 19 observers along 31 road routes (total of $7869 \mathrm{~km}$ ) between 19 June and 19 July. Observers recorded 151 shrikes at 121 unique locations, for a linear density of 1.54 indicated pairs (IP)/100 km of route. This value is $14.9 \%$ lower than was observed during the 2003 survey $(1.81 \mathrm{IP} / 100 \mathrm{~km})$, and $22.6 \%$ less than values calculated in 1998. Despite these declines, populations remain substantially higher than in $1987(0.48 \mathrm{IP} / 100 \mathrm{~km})$, although values reported that year may be erroneously low. The highest linear density of shrikes was found in map sheets $72 \mathrm{M}(4.07 \mathrm{IP} / 100 \mathrm{~km})$ and $72 \mathrm{~L}(3.75 \mathrm{IP} / 100 \mathrm{~km})$, with the lowest number being found in sheet $82 \mathrm{H}$ (no shrikes). Since 1993, populations have declined steadily in map sheets $72 \mathrm{~L}, 72 \mathrm{M}$ and $82 \mathrm{I}$, have remained relatively steady in $72 \mathrm{E}, 73 \mathrm{D}, 82 \mathrm{P}$ and $82 \mathrm{H}$, and increased only in sheet $83 \mathrm{~A}$. Since 2003, populations have declined on five map sheets (72E, 72L, 72M, 82 H and 82I), and increased in only three $(73 \mathrm{D}, 82 \mathrm{P}, 83 \mathrm{~A})$. A provincial population estimate of 7721 Loggerhead Shrike pairs in Alberta during 2008 is a $7.3 \%$ decline from values calculated from the 2003 survey.

Most occupied sites were in areas of mixed trees and shrubs (30.5\%), followed by occupied farmsteads $(17.8 \%)$, shelterbelts and thorny buffalo berry $(15.3 \%$ each). Native grass was present at most $(60.9 \%)$ sites, although numerous occupied sites contained tame pasture $(57.3 \%)$ and cultivation $(53.0 \%)$. Fourteen nests were found during the survey with $64.3 \%$ occurring in willows.

Validation of the HSI model involved comparison of habitat values at 265 occupied locations (2003 and 2008 roadside surveys combined) with an equal number of random points along roadsides in the landscape. Mean HSI values did not differ between random and occupied points at either a $200 \mathrm{~m}$ or $1000 \mathrm{~m}$ scale at a provincial level, nor were there overall differences in the mean proportion of HSI scores $>0.4,>0.6$ and $>0.8$ at either scale. However, mean HSI scores, as well as the proportion of scores in various categories were significantly higher where shrikes occurred in map sheet $83 \mathrm{~A}$ at both the $200 \mathrm{~m}$ and $1000 \mathrm{~m}$ scales. The failure of the HSI model to predict shrike occupancy, except possibly in the parkland areas of the province, suggests that improved models are required to be an effective management tool for Loggerhead Shrikes in this province. 


\subsection{INTRODUCTION}

Loggerhead Shrike (Lanius ludovicianus) populations have declined in recent years across most of North America (Sauer et al. 2008). In Canada, the eastern subspecies (L. l. migrans) is now listed as an "Endangered" species by the Committee on the Status of Endangered Wildlife in Canada, whereas western populations (L. l. exubitorides) are considered to be "Threatened" (COSEWIC 2008). In Alberta, the Loggerhead Shrike is listed as a species of "Special Concern" (Alberta Fish and Wildlife Division 2008). Populations in this province, as in many other jurisdictions, have declined since the 1950s (Prescott and Bjorge 1999, Sauer et al. 2008). Recent estimates have suggested a population of about 8000 pairs in Alberta (Prescott 2004).

A variety of surveys have been conducted for the Loggerhead Shrike in Alberta over the past two decades (Telfer et al. 1989, Bjorge and Prescott 1996, Collister 1996, Bjorge and Kiliaan 1997, Kiliaan and Prescott 2002, Prescott 2003, 2004). The most useful survey for monitoring large-scale population trends has been the prairie-wide roadside survey conducted at five-year intervals since 1987 (the 1993 survey was not conducted in this province). These surveys have covered between 10,000 and 14,000 $\mathrm{km}$ of roadside habitat across the prairies, including between $3800 \mathrm{~km}$ (1987 and 1998) and $8095 \mathrm{~km}$ (2003 survey) in Alberta. Roadside surveys have shown that populations in Alberta have increased since the 1987 inventory, with populations in Saskatchewan remaining fairly stable, and those in Manitoba decreasing markedly (Johns et al. 2002, Prescott 2004, St. Laurent et al. 2009).

This report summarizes the Alberta portion of the Loggerhead Shrike roadside survey conducted in 2008. The main intent of the survey was to continue monitoring population trends and distribution of this species at risk on the Canadian prairies. This report also combines site-location data collected during the 2008 survey with similar data collected during 2003 to validate a Habitat Suitability Index (HSI) model that has been developed to predict the occurrence of Loggerhead Shrikes in Alberta (Downey 2004).

\subsection{METHODS}

\section{$\underline{2.1 \text { Field Survevs }}$}

Surveys were conducted along roads within the range of the Loggerhead Shrike in Alberta. In the 1987 and 1998 surveys, two road routes, averaging about $260 \mathrm{~km}$ in length, were established in each of the eight, 1:250,000 map sheets in the southeastern part of the province (total of $3802 \mathrm{~km}$ ). For the 2003 and 2008 surveys, the same routes were maintained, but an additional two routes were placed in all map sheets, with the exception of sheet $72 \mathrm{~L}$ in the southeastern corner of the province, where a paucity of roads permitted the addition of only one route (see Figure 1). The addition of these routes was intended to better monitor local shifts in the population between survey periods, to potentially detect previously unknown concentrations of breeding birds, and to derive population estimates from a higher percentage of the actual breeding population. The 31 routes totaled $8095 \mathrm{~km}$ (based on 2003 driving distances). 


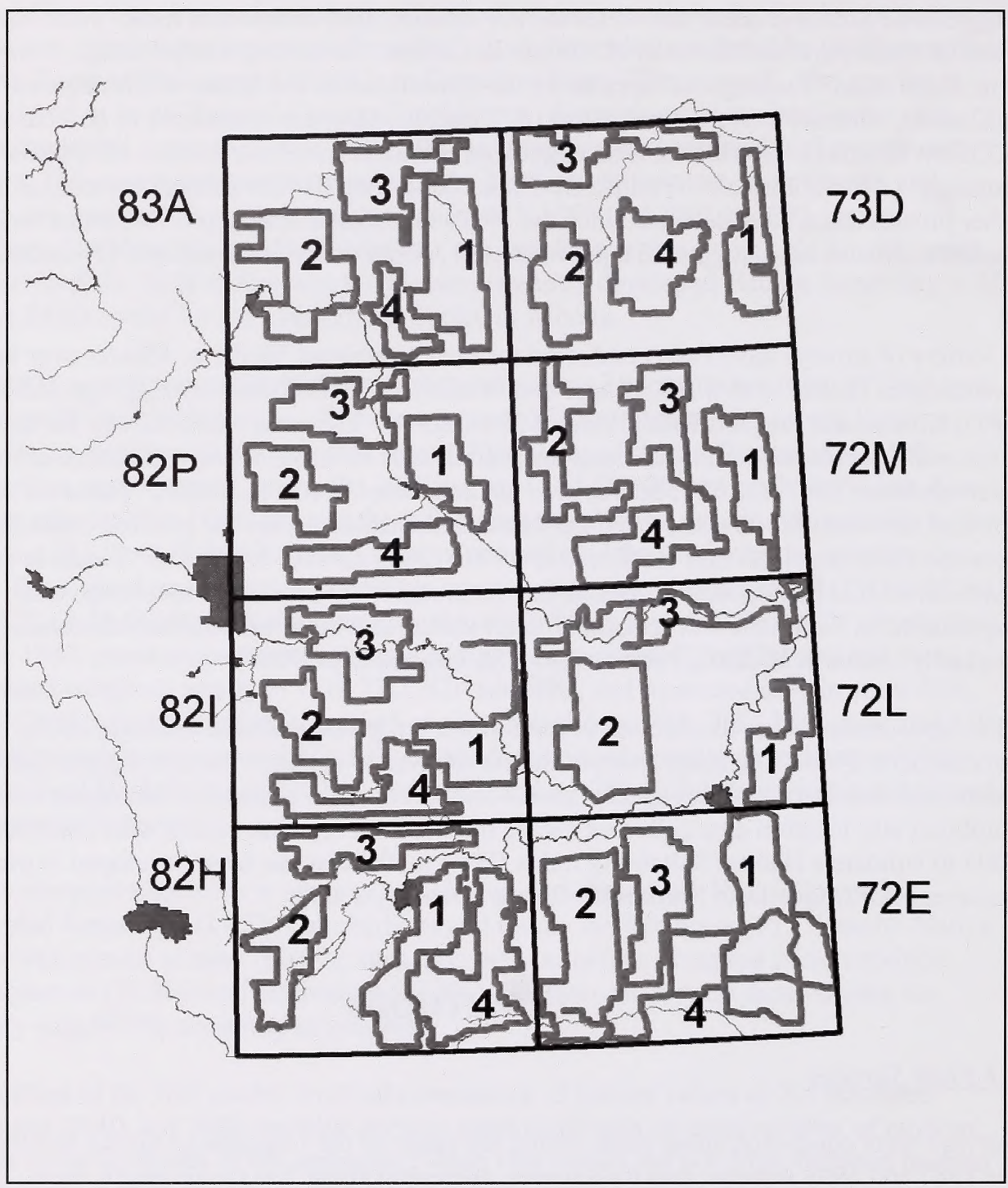

Figure 1. Location of road survey routes used in the 2008 Loggerhead Shrike survey in Alberta. In each map sheet, routes 1 and 2 were also surveyed in previous provincial inventories in 1987 and 1998. Routes 3 and 4 in each map sheet were added for the 2003 and 2008 surveys.

Surveys were conducted using identical methodology to that used in the previous four surveys conducted across the prairies (three in Alberta; see Telfer et al. 1989, Johns et al. 2002, Prescott 2004). Participants drove routes at speeds of $50-70 \mathrm{~km} / \mathrm{hr}$ between mid-June and mid- 
July, and recorded the presence of shrikes using hand-held GPS units (UTM NAD 83). Observers were permitted to slow down or stop in areas of suitable habitat to better determine the presence of birds. Each occupied site was assumed to represent a breeding pair ("indicated pair"), whether or not a pair was observed. Surveys were not conducted during inclement weather or temperatures $>25^{\circ} \mathrm{C}$. In Alberta, we also asked observers to collect additional information on habitats where shrikes were observed, including (1) general description of woody vegetation (abandoned farm, occupied farm, dry slough, aspen [Populus spp.] groves, shelterbelt, thorny buffalo berry [Sheperdia argentea], upland willow [Salix spp.], mixed shrub/tree, other); (2) percentage of different grassland types (native, tame, cultivated) within a $200 \mathrm{~m}$ radius of the observation site, and (3) type of nesting shrub, if nest was observed or strongly inferred from adult behavior (generally carrying food). For these summaries, data from road routes were combined with similar data from incidental observations of shrikes collected during the survey period (i.e., while driving to and from routes).

All records of shrikes, including incidental observations made during 2008, were entered into the Fish and Wildlife Management Information System (FWMIS), maintained by Alberta Fish and Wildlife Division.

\subsection{Analvsis}

Shrike observations were compiled for each map sheet ( 3 or 4 routes combined), and the number of shrikes expressed as indicated pairs (IP) per $100 \mathrm{~km}$. These values were compared across time intervals with data collected during the previous three surveys in Alberta on both a map sheet, and provincial basis.

A population estimate (\# indicated pairs) for the each 1:250,000 map sheet was derived from:

$$
I P=(\# \text { observed IP } / \mathrm{km}) *(\mathrm{~km} \text { of roads in map sheet }) * 7.53
$$

where 7.53 represents a correction factor calculated by Prescott (2004). This value is determined from the proportion of observed shrikes on roadside surveys that are found within $100 \mathrm{~m}$ of roads ( 0.845 ; calculated from 2003 survey data), divided by the proportion of shrikes within $100 \mathrm{~m}$ that are actually detected during these surveys $(0.34)$ and the percentage of shrikes on the landscape that actually occur within $100 \mathrm{~m}$ of roads $(0.33$; determined from block data of Bjorge and Prescott [1996] and Bjorge and Kiliaan [1997]). In other words, each indicated pair of shrikes along a surveyed road actually represents 7.53 pairs on the landscape around those surveyed roads. The product of the observed IP/ $\mathrm{km}$, the correction factor, and the $\mathrm{km}$ of roads on the map sheet as a whole produces an approximate population estimate for that map sheet. The value derived from each map sheet was then summed to produce a provincial population estimate.

\subsection{HSI Model Validation}

Habitat Suitability Index (HSI) models were originally developed by the U.S. Fish and Wildlife Service in the early 1980 s to produce numerical ratings of habitat units that could predict the occurrence of individual wildlife species (see U.S. Fish and Wildlife Service 1981, 
Schamberger et al. 1982). Models may be produced in a variety of ways, but are often based on assumed (e.g. expert opinion) or measured (i.e through statistical techniques such as regression) responses of the animal to variations in a relatively small number of habitat attributes. The responses to individual factors are then combined through a simple mathematical relationship, to produce an HSI value between 0 (no suitability) and 1 (highly suitable) for particular habitat units (Morrison et al. 2006).

In Alberta, an HSI model for Loggerhead Shrikes was developed for the Milk River basin (extreme southern Alberta) by Downey (2004). The model was built from published references and expert opinion, and included the anticipated responses of shrikes to four habitat variables: shrub coverage $\left(\mathrm{V}_{1}\right)$, graminoid cover $\left(\mathrm{V}_{2}\right)$, topographical slope $\left(\mathrm{V}_{3}\right)$, and the presence of farmyards $\left(\mathrm{V}_{4}\right)$; see Downey (2004) for description of these relationships. HSI values were then generated for $25 \times 25 \mathrm{~m}$ cells on the landscape from the equation:

$$
\mathrm{HSI}=\left(\mathrm{V}_{1} * \mathrm{~V}_{2} * \mathrm{~V}_{3}\right)^{1 / 3}+\left(0.25 * \mathrm{~V}_{4}\right) .
$$

The original extent of the HSI model for Loggerhead Shrikes was later expanded to the entire Grassland Natural Region of Alberta.

To validate the HSI model, I collated all locations of shrikes gathered during the 2003 and 2008 roadside surveys on individual 1:250,000 map sheets. GIS was then used to randomly generate an equal number of sites in each map sheet. These sites were centered along primary and secondary highways. A variety of HSI metrics were calculated (see below) at two scales $(200 \mathrm{~m}$ and $1000 \mathrm{~m})$ around actual and random points. The smaller radius approximates the average territory size of Loggerhead Shrikes in Alberta (13.4 ha) as determined by Collister (1994), whereas the larger radius was arbitrarily chosen to consider that shrikes may respond to landscape features at a scale larger than their individual nesting territory. For each buffer size, I calculated the mean HSI value, and the proportion of the buffer with HSI values $>0.8,>0.6$, and $>0.4$. These four metrics were compared between random and actual observation points at each scale using one-tailed Mann-Whitney U-tests (Conover 1980). The hypothesis was that a useful HSI model should yield significantly larger habitat values in areas where shrikes actually occur, relative to randomly-generated points on the same landscape.

\subsection{RESULTS}

\section{$\underline{3.1 \text { Field Survevs }}$}

A total of 19 observers from Alberta Fish and Wildlife and the Alberta Conservation Association spent 174 hours surveying the 31 shrike routes between 19 June and 19 July 2008. The total road distance surveyed was $7869 \mathrm{~km}$, which was $2.8 \%$ shorter than the total distance travelled along these same routes in $2003(8095 \mathrm{~km})$. The difference in these values reflects differences amongst individual observers in how odometer readings were reported, as well as factors such as road conditions (weather, construction and heavy traffic) that resulted in small adjustments to individual routes. These routes represented approximately $10.1 \%$ of available roads in the provincial study area, with percentages in individual map sheets ranging from $7.1 \%$ (Map 83A) to $18.1 \%$ (Map 72L) (Table 1). 
Observers encountered 151 shrikes ( 97 single birds, 27 pairs) at 121 unique sites, for a total of 1.54 indicated pairs [IP]/100 km of route. The highest linear density of shrikes was found in map sheets $72 \mathrm{M}(4.07 \mathrm{IP} / 100 \mathrm{~km})$ and $72 \mathrm{~L}(3.75 \mathrm{IP} / 100 \mathrm{~km})$, with the lowest number being found in sheet $82 \mathrm{H}$ (no shrikes; Table 1). The observed value of $1.54 \mathrm{IP} / 100 \mathrm{~km}$ in 2008 is $14.9 \%$ less than the 1.81 pairs $/ 100 \mathrm{~km}$ reported in 2003 , and $22.6 \%$ less than values calculated in 1998. However, populations remain substantially $(220.8 \%)$ higher than during the inaugural survey in 1987 (0.48 IP/100 km), and are higher on all map sheets compared to 1987 values (except for sheet $82 \mathrm{H}$ where shrikes were absent in both surveys (Table 2). Since 1993, populations have declined steadily in map sheets $72 \mathrm{~L}, 72 \mathrm{M}$ and $82 \mathrm{I}$, have remained relatively steady in $72 \mathrm{E}, 73 \mathrm{D}, 82 \mathrm{P}$ and $82 \mathrm{H}$, and increased only in sheet $83 \mathrm{~A}$ (Table 2). Since the last survey in 2003, populations have declined on five map sheets (72E, 72L, 72M, 82H and 82I), and increased in only three $(73 \mathrm{D}, 82 \mathrm{P}, 83 \mathrm{~A})$.

Extrapolations of roadside observations to the landscape as a whole suggests a total provincial population of 7721 loggerhead shrike pairs in Alberta during 2008. This represents a 7.3\% decline from the estimate ( 8327 pairs) made from the 2003 survey (Prescott 2004). The largest population occurred in map sheet $72 \mathrm{M}$ (2197 pairs), and the lowest in map sheet $82 \mathrm{H}$ ( 0 pairs; Table 1).

Characterization of habitat was based on 118 sites (110 on roadside routes, 8 during incidental observations) where shrikes were observed during the 2008 survey period. Most woody vegetation where shrikes were found was described as being of mixed trees and shrubs (30.5\%), followed by occupied farmsteads $(17.8 \%)$, shelterbelts and thorny buffalo berry (15.3\% each), dry slough margins and upland willow (9.3\% each), abandoned farmsteads $(1.7 \%)$, and other (chokecherry grove; $0.8 \%$ ). Native grass was present at 71 of 117 sites $(60.9 \%)$, with tame pasture $(57.3 \%)$ and cultivation being well represented as well (53.0\%). Forty-four sites were made up of a single grass type, with native grass being the most commonly encountered ( $63.6 \%$ of sites), versus $22.7 \%$ for cultivation and $13.6 \%$ for tame grass. Nine sites $(7.7 \%)$ had all three types of grass cover within $200 \mathrm{~m}$ the observation point.

Fourteen nests were found during the survey (11 observed, 3 inferred from behavior); with 9 $(64.3 \%)$ being found in willows and the remaining four (28.6\%) in thorny buffalo berry.

\subsection{HSI Model Validation}

A total of 265 unique shrike observations were collated from the 2003 and 2008 roadside surveys, with the number of shrikes in each map sheet varying from $1(82 \mathrm{H})$ to $87(72 \mathrm{M})$. A similar number of random points were generated across map sheets. Comparisons of HSI values were conducted at each scale $(200 \mathrm{~m}$ and $1000 \mathrm{~m})$ within each map sheet $(82 \mathrm{H}$ excluded because of small sample size), and over all observations combined. 
Table 1. Summary of Loggerhead Shrike roadside survey results in each of eight, 1:250,000 map sheets in southeastern Alberta in 2008.

\begin{tabular}{|c|c|c|c|c|c|c|c|c|}
\hline $\begin{array}{l}\text { Map } \\
\text { Sheet }\end{array}$ & $\begin{array}{c}\# \\
\text { Transects }\end{array}$ & $\begin{array}{l}\text { Total km } \\
\text { Surveyed }\end{array}$ & $\begin{array}{c}\text { Total } \\
\text { Roads in } \\
\text { Map Sheet } \\
(\mathrm{km})\end{array}$ & $\begin{array}{l}\% \text { Road } \\
\text { Surveyed }\end{array}$ & $\begin{array}{l}\text { Total } \\
\text { Birds }\end{array}$ & IP & $\mathrm{IP} / 100 \mathrm{~km}$ & $\begin{array}{l}\text { Population } \\
\text { Estimate } \\
\text { (pairs) }^{1}\end{array}$ \\
\hline $72 \mathrm{E}$ & 4 & 1144 & 8732 & 13.1 & 13 & 10 & 0.874 & 574.7 \\
\hline $72 \mathrm{~L}$ & 3 & 880 & 4875 & 18.1 & 44 & 33 & 3.75 & 1376.6 \\
\hline $72 \mathrm{M}$ & 4 & 1008 & 7175 & 14.0 & 43 & 41 & 4.067 & 2197.3 \\
\hline $73 \mathrm{D}$ & 4 & 910 & 10796 & 8.4 & 15 & 9 & 0.989 & 804.0 \\
\hline $82 \mathrm{H}$ & 4 & 1049 & 10545 & 10.3 & 0 & 0 & 0 & 0 \\
\hline $82 \mathrm{I}$ & 4 & 1015 & 10460 & 10.0 & 5 & 5 & 0.493 & 388.3 \\
\hline $82 \mathrm{P}$ & 4 & 911 & 12088 & 7.5 & 19 & 11 & 1.207 & 1098.6 \\
\hline $83 \mathrm{~A}$ & 4 & 952 & 13502 & 7.1 & 12 & 12 & 1.261 & 1281.6 \\
\hline TOTAL & 31 & 7869 & 78173 & 10.1 & 151 & 121 & 1.54 & 7721.1 \\
\hline
\end{tabular}

${ }^{1}$ See text for calculations

Table 2. Number of indicated breeding pairs (IP) per $100 \mathrm{~km}$ of road, and percentage change in population size among three roadside surveys conducted in Alberta. Values are based on 31 routes surveyed in 2003 and 2008, and 16 routes in 1987 and 1998.

$\mathrm{IP} / 100 \mathrm{~km}$

$\%$ change $^{1}$

$\begin{array}{lllllll}\text { Map sheet } \quad 1987 & 1998 & 2003 & 2008 & 1987-2008 & 1998-2008 & 2003-2008\end{array}$

\begin{tabular}{cccccccc}
\hline $72 \mathrm{E}$ & 0.82 & 0.82 & 1.56 & 0.87 & 6.1 & 6.1 & -44.2 \\
$72 \mathrm{~L}$ & 0.95 & 5.24 & 5.01 & 3.75 & 294.7 & -28.4 & -25.1 \\
$72 \mathrm{M}$ & 1.85 & 5.19 & 4.48 & 4.07 & 120.0 & -21.6 & -9.2 \\
$73 \mathrm{D}$ & 0.00 & 0.95 & 0.91 & 0.99 & ++ & 4.2 & 8.8 \\
$82 \mathrm{H}$ & 0.00 & 0.00 & 0.09 & 0.00 & $\mathrm{~N} / \mathrm{C}$ & $\mathrm{N} / \mathrm{C}$ & -- \\
$82 \mathrm{I}$ & 0.22 & 2.15 & 0.62 & 0.49 & 122.7 & -77.2 & -21.0 \\
$82 \mathrm{P}$ & 0.00 & 1.58 & 0.90 & 1.21 & ++ & -23.4 & 34.3 \\
$83 \mathrm{~A}$ & 0.00 & 0.00 & 0.92 & 1.26 & ++ & ++ & 37.0 \\
\hline OVERALL & 0.48 & 1.99 & 1.81 & 1.54 & 220.8 & -22.6 & -14.9 \\
\hline
\end{tabular}

${ }^{1}++$ denotes birds now present where previously absent; - denotes birds absent where previously present; $\mathrm{N} / \mathrm{C}=$ No change. 
Mean HSI values did not differ between random and actual points at either the $200 \mathrm{~m}$ (Table 3 ) or $1000 \mathrm{~m}$ (Table 4) scales at a provincial level ( $>>0.10)$, nor were there overall differences in the mean proportion of HSI scores $>0.4,>0.6$ and $>0.8$ at either scale. However, mean HSI scores, as well as the proportion of scores in various categories were significantly higher where shrikes occurred in map sheet 83A. These differences occurred at both the $200 \mathrm{~m}$ (Table 3) and $1000 \mathrm{~m}$ (Table 4) scales.

\subsection{DISCUSSION}

Loggerhead Shrike populations in Alberta have declined steadily over the past decade. In 2008 , we found an overall linear density of 1.54 shrike pairs per $100 \mathrm{~km}$ of road. This represents a $14.9 \%$ decline from a similar survey in 2003 , and a $22.6 \%$ reduction since 1998 . Over this period, there has been a general reduction in populations from areas with the highest traditional density of shrikes (map sheets $72 \mathrm{M}, 72 \mathrm{~L}$ and $72 \mathrm{M}$ ), and a modest increase only in the parkland region (map sheet 83A). However, overall populations remain substantially $(220 \%)$ higher than during the inaugural survey in $1987(0.48$ pairs $/ 100 \mathrm{~km})$, and are higher on all map sheets except $82 \mathrm{H}$ where populations are virtually non-existent. It is very likely, however, that population indices calculated during that first survey are too low, and that current populations are not actually higher than observed in 1987. Breeding Bird Survey (BBS) data (Sauer et al. 2008) for Alberta show that populations in the province were $28 \%$ higher in 1987 than they were in 2003, and 35\% higher than they were in either 2003 or 2007 (the most recent year of data available). Although BBS surveys are not likely to encounter as many shrikes as the roadside routes used specifically for shrike surveys since 1987, BBS effort and observers are relatively comparable over time. It is possible that values obtained from the roadside shrike survey during the first survey in 1987 were lower than expected due to observer inexperience or other factors. Even without consideration of the 1987 data, it is clear that Loggerhead Shrike populations in Alberta have declined in recent years. The population estimate of 7721 breeding pairs suggests that the species is not in imminent danger of extirpation in the province, but ongoing monitoring will be necessary to make sure populations do not decline to critical levels.

The trend in Alberta populations is mirrored in Saskatchewan, which supports the highest numbers of breeding Loggerhead Shrikes in Canada (Cadman 1985). Populations increased by $75 \%$ between the first two road surveys (1987 and 1993), even though BBS data for the province showed a $42 \%$ decline during this period (Sauer et al. 2008). Roadside data have subsequently shown a $69 \%$ drop since 1993 , including a notable $59 \%$ drop over the past five years (St. Laurent et al. 2009). Manitoba has had very low populations for the past few decades, with populations having declined approximately 40\% since 2003 and $70 \%$ since 1998 (K. De Smet, pers. comm.). Comparable roadside surveys are not conducted in adjacent areas of the United States, but BBS data show steady, and in some cases rapid declines throughout the Midwestern states and in most other areas of the species' North American range (Sauer et al. 2008). 


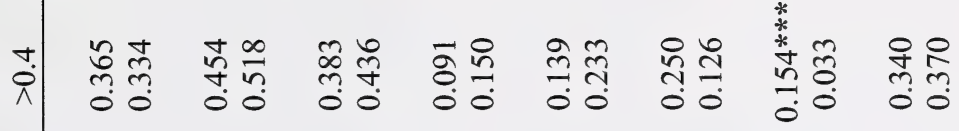

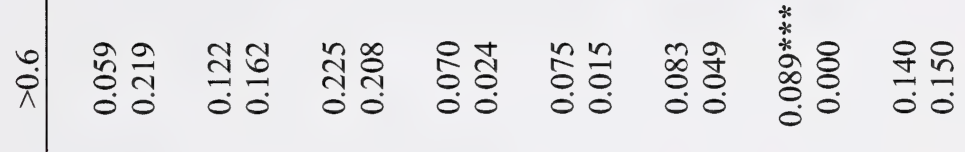

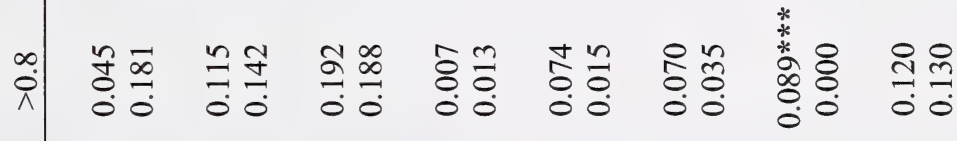

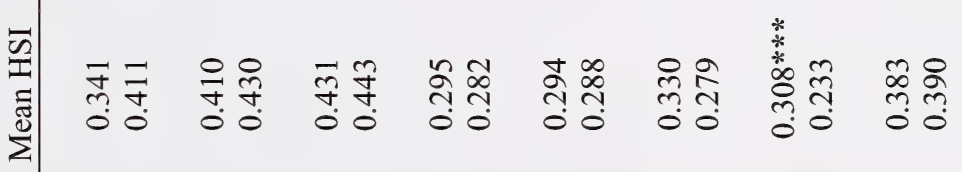

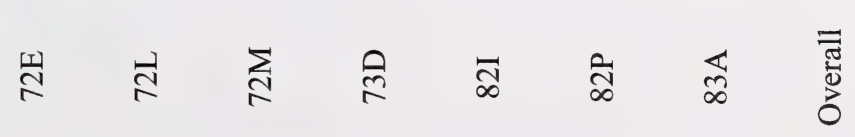


The Loggerhead Shrike is not an intensively managed species in Alberta, although there have been limited attempts to protect important habitats, enhance shrub cover, promote stewardship, and educate the public about shrike conservation and management (Collister 1994, Prescott and Bjorge 1999, Operation Grassland Community 2005). If populations continue to decline, it may be necessary to more actively manage this species. However, Loggerhead Shrikes occur at low densities over a wide range in Alberta, and much of the range has not been intensively surveyed. There is therefore utility in developing accurate habitat models the can focus the attention of wildlife managers where concentrations of shrikes likely occur, and where management actions can have the most impact. In Alberta, HSI models for a variety of species are being increasingly used for this purpose (e.g. Downey et al. 2004). However, the current model for Loggerhead Shrikes does not adequately predict the presence of shrikes on the landscape, with the possible exception of the aspen parkland region of the province. This is not surprising, as HSI models for most other species have performed poorly when validated (Bart et al. 1984, Cole and Smith 1983). It has been argued that HSI models are overly simplistic, and fail to account for interactions between variables on habitat use by the species of interest (Bart et al. 1984, Morrison et al. 2006.)

The specific reasons for the failure of the Alberta HSI model to predict shrike occurrence in most areas of the province are unknown. One factor is certainly the inability of the GIS coverages available at the time of HSI model development to distinguish between size classes and species of shrubs (A. Violette, pers. comm.). Consequently, all areas of shrub would appear to be suitable shrike habitat, although most nesting shrubs in Alberta are 2-3 m tall (unpubl. data., see also Collister 1994), and preferences for nesting in species such as thorny buffalo berry and willow are well known (Collister 1994). Other factors important in habitat selection by Loggerhead Shrikes, such as the configuration of shrubs and foraging perches within territories (Yosef and Grubb 1994), and the height and heterogeneity of grass cover (Prescott and Collister 1993, Bjorge and Prescott 1996), are also not considered in the current HSI model. New GIS coverages, currently being completed through the provincial Grassland Vegetation Inventory (GVI), will provide much improved resolution for upland vegetation including shrubs and grass cover (A. Violette, pers. comm.). Recalculation and re-validation of HSI models using improved GIS coverages should be completed before HSI models are used as a management tool for Loggerhead Shrikes in Alberta.

\subsection{RECOMMENDATIONS/FUTURE DIRECTION}

Loggerhead Shrikes favor native grasslands in Alberta, but a high proportion of observations also occur in human-altered landscapes (crop and tame pastures, farmsteads and shelterbelts). Despite the apparent availability of nesting habitat in the province, the Loggerhead Shrike remains a relatively rare species within its Alberta range. This, along with fairly strong population declines in recent years, is reason for concern. A number of recommendations based on this concern, and the outcome of the 2008 roadside survey can be made: 
1. Participation in the prairie-wide road census should continue, with the next survey scheduled for 2013. These surveys remain the most effective way to monitor population size in Alberta relative to size and trends in population in adjacent provinces.

2. Encourage research and stewardship efforts to understand and mitigate factors responsible for the recent decline in shrike populations in Alberta, and elsewhere in their North American range

3. Preparation and validation of improved habitat suitability models for Loggerhead Shrikes in the province. These models should incorporate recent improvements in GIS coverages (e.g. GVI data), and perhaps use more rigorous model-building approaches (e.g. Resource Selection Functions) than HSI modeling can provide.

4. Preparation of a management plan for Alberta. Such a plan, which is recommended for all species of "Special Concern" in the province, should be completed as soon as the national recovery plan for the prairie Loggerhead Shrike is finalized (currently in preparation). This will ensure integration of the provincial and national management approaches for this species. 


\subsection{LITERATURE CITED}

Alberta Fish and Wildlife Division. 2008. Report of Alberta's Endangered Species Conservation Committee: June 2006. Alberta Sustainable Resource Development, Fish and Wildlife Division, Edmonton, AB. 44 pp.

Bart, J., D. R. Petit, and G. Linscomb. 1984. Field evaluation of two models developed following the habitat evaluation procedures. Trans. N. A. Wildl. Nat. Res. Conf. 49:498499.

Bjorge, R. R., and H. Kiliaan. 1997. Densities of Loggerhead Shrikes on study blocks in southeastern Alberta inventoried in both 1993 and 1996. Blue Jay 54: 217-219.

Bjorge, R. R., and D. R. C. Prescott. 1996. Population estimate and habitat associations of the Loggerhead Shrike, Lanius ludvicianus, in southeastern Alberta. Can. Field-Natur. 110:445-449.

Cadman, M. D. 1985. Status report on the Loggerhead Shrike (Lanius ludovicianus) in Canada. COSEWIC report, Ottawa, Ont.

Cole, C. A., and R. L. Smith. 1983. Habitat suitability indices for monitoring wildlife populations. Trans. N. A. Wildl. Nat. Res. Conf. 48:367-375.

Collister, D. M. 1994. Breeding ecology and habitat preservation of the Loggerhead Shrike in southeastern Alberta. M.S. thesis. University of Calgary, Calgary, Alberta. 161 pp.

Collister, D. M. 1996. Population survey of Loggerhead Shrike, Lanius ludovicianus exubitorides, nesting pairs Bassano Subdivision-Atlee to Cavendish. Unpubl. rept. For Alberta Environmental Protection. 9 pp.

Conover, W. J. 1980. Practical nonparametric statistics, $2^{\text {nd }}$ ed. John Wiley and Sons, New York, NY. 493 pp.

COSEWIC. 2008. Canadian wildlife species at risk, December 2008. Committee on the Endangered Wildlife in Canada, Ottawa, ON. 86 pp.

Downey, B. A. 2004. Loggerhead Shrike (Lanius ludovicianus excubitorides). Pp. 28-35 in MULTSAR: The Milk River basis habitat suitability models for selected wildlife species (B.A. Downey, B.L. Downey, R. W. Quinlan, O. Castelli, V. J. Remesz and P. F. Jones, eds.). Alberta Sustainable Resource Development, Fish and Wildlife Division, Alberta Species at Risk Report No. 86, Edmonton, AB. 135 pp.

Downey, B. A., B. L. Downey, R. W. Quinlan, O. Casetelli, V. Remesz, and P. F. Jones. 2004. MULTSAR: The Milk River basis habitat suitability models for selected wildlife species. 
Alberta Sustainable Resource Development, Fish and Wildlife Division, Alberta Species at Risk Report No. 86, Edmonton, AB. 135 pp.

Johns, B., D. Collister, R. Bjorge, K. De Smet, W. Harris, E. Wiltse, and S. Barry. 2002. Loggerhead Shrike population trends in western Canada. Can. Wildl. Serv. Progr. Notes No. 218. $6 \mathrm{pp}$.

Kiliaan, H., and D. R. C. Prescott. 2002. Survey of the Loggerhead Shrike in the southern aspen parkland region, 2000-2001. Alberta Sustainable Resource Development, Fish and Wildlife Division, Alberta Species at Risk Report No. 46, Edmonton, AB. 10 pp.

Morrison, M. L., B. G. Marcot, and R. W. Mannan. 2006. Wildlife-habitat relationships: concepts and applications, $3^{\text {rd }}$ ed. Island Press, Washington, DC. 493 pp.

Operation Grassland Community. 2005. Loggerhead Shrike census and management plans. Pp. 4 in Prairie Acres (newsletter), Winter 2005.

Prescott, D. R. C., and D. M. Collister. 1993. Characteristics of occupied and unoccupied Loggerhead Shrike territories in southeastern Alberta. J. Wildl. Manage. 57:346-352

Prescott, D. R. C. 2003. The use of call playbacks for censusing Loggerhead Shrikes in southern Alberta. Alberta Sustainable Resource Development, Fish and Wildlife Division, Alberta Species at Risk Report No. 67, Edmonton, AB. 10 pp.

Prescott, D. R. C. 2004. The 2003 Loggerhead Shrike survey in Alberta. Alberta Sustainable Resource Development, Fish and Wildlife Division, Alberta Species at Risk Report No.93, Edmonton, AB. 10 pp.

Prescott, D. R. C., and R. R. Bjorge. 1999. Status of the Loggerhead Shrike (Lanius ludovicianus) in Alberta. Alberta Natural Resources Services, Edmonton, AB. 28 pp.

Sauer, J. R., J. E. Hines, and J. Fallon. 2008. The North American Breeding Bird Survey, Results and Analysis 1966 - 2007. Version 5.15.2008. USGS Patuxent Wildlife Research Center, Laurel, MD. http://www.mbr-wrc.usgs.gov/bbs/bbs.html

Schamberger, M., A. H. Farmer, and J. W. Terrell. 1982. Habitat suitability index models:introduction. U.S.D.I. Fish and Wildlife Service FWS/OBS-82/10, Washington, DC.

St. Laurent, K., A. Didiuk, L. Craig-Moore and B. Johns. 2009. Prairie Loggerhead Shrike (Lanius ludovicianus excubitorides) Saskatchewan five-year survey summary 19872008. Unpublished Draft Report, Canadian Wildlife Service, Saskatoon SK. 131 pp.

Telfer, E. S., C. Adam, K. DeSmet, and R. Wershler. 1989. Status and distribution of the Loggerhead Shrike in western Canada. Can. Wildl. Serv. Progr. Notes No. 184. 4 pp. 
U.S. Fish and Wildlife Service. 1981. Standards for the development of habitat suitability index models for use in the Habitat Evaluation Procedures. U.S.D.I. Fish and Wildlife Service. Division of Ecological Services. ESM 103, Washington, DC.

Yosef, R., and T. C. Grubb Jr. 1994. Resource dependence and territory size in Loggerhead Shrikes (Lanius ludovicianus). Auk 111:465-469. 
For a list of additional reports in the Alberta Fish and Wildlife Division - Species at Risk Series please go to our website:

http://srd.alberta.ca/fishwildlife/speciesatrisk/projectreports.aspx 
LIBRARY AND ARCHIVES CANADA

33286544594050

$\sqrt{3}$

FSC

Mixed Sources

product group from well-managed

recycled wood or fibre

Cert no. SW-COC-003027

Www.fsc.org
- 1996 forest Stewardship Council 